\title{
The transmission of Rabbi Moses Arragel: Maqueda, Paris, London
}

\author{
Eleazar GUTWIRTH * \\ University of Tel Aviv
}

Political appropriations, disciplinary priorities and technological change are three distinct factors which affect the intellectual field of fifteenth century Hispano-Jewish studies. The Arragel Bible, produced in Castile c. 1422-1430/33, could be seen as just another book in a large library of the period or as another link in a long chain extending from the Bible translations of the Hellenistic world to those of today's heder. As has been noticed a long time ago, this is not the case. The question of Arragel's Biblia, its transmission and Rezeptionsgeschichte acquires a renewed currency thanks to two publications: 1) The facsimile and companion volume (Madrid 1992) and 2) the recent (2002) publication of Sonia Fellous' study based on her Paris doctoral thesis of the 1980's. ${ }^{1}$

*gutwirth@post.tau.ac.il.

1 JEREMY SCHONFIELD (coord.), La Biblia de Alba: an illustrated, etc., 2 vols. (Madrid 1992); Sonia Fellous, «Le Rabbin Mose Arragel de Guadalajara à travers son oeuvre: La Bible du duc d'Albe (1422-1433?),»REJ 146 (1987) pp. 496-503; ID., Tolède 1422-1433. Histoire de la Bible de Moise Arragel. Quand un rabbin interprète la Bible pour les Chrétiens (Paris 2002) [There is a Spanish translation].

Sefarad 63 (2003) págs. 69-87

(C) CSIC

ISSN 037-0894 


\section{I}

A Bible written in Maqueda by a Jew -a Rabbi-for the Master of a Christian military/religious Order, namely that of Calatrava, is popularly seen as a symbol of «toleration.» This brings us to our first point, that of disciplinary differences. There are indeed some types of studies (e.g. in folklore or language), where chronology is not and cannot be a priority because of the material itself. In the case of «toleration,» historians have long ago ceased to employ it colloquially as a kind of timeless moral quality. ${ }^{2}$ The appearance of the ideas or terms in the writings of Roger Williams, John Locke, James Harrington and the practical legislation of the Tolerantzpatenten of enlightened absolutists (e.g. Joseph II) i.e. published, coherent, political argument and practical legislation, constitute the chronological and geographic framework of the term «toleration» as applied by historians to the history of the Jews.

Such legal texts bring us to our second point, that of the relation between legal texts and the Arragel Bible. The highly influential view of Joseph Gutmann ${ }^{3}$ and his followers is that the relations are very close. For him, the major advance in Arragel studies, that of Carl-Otto Nordström, is defective. The Bible must be understood against the background of Spanish Jewish history, a dimension overlooked by Nordström (p. 92). History, for Gutmann, is reduced to or subsumed in one main fact: «in the year 1412, the government of Castile promulgated in the city of Valladolid antisocial regulations and severe, restrictive economic ordinances ... reduced the remaining Jews to ... miserable status ...» (p. 93). The Statutes -obviously discriminatory- are invoked by appeal to Baer. Nevertheless, the view of Gutmann is very similar to that of Graetz. ${ }^{4}$

\footnotetext{
2 Hence the constant search for -and discarding of-alternative concepts such as encounters, cultures in contact, coexistence, interaction, cohabitation, etc.

3 Joseph Gutmann, Art Bulletin 51 (1969) pp. 91-96. See also Thérèse METZGER, «The Alba Bible of Rabbi Moses Arragel,» Journal of Jewish Studies 26 (1975) pp. 131-155.

4 For the evidence on Graetz see for example Eleazar GUTwIRTH, «The Politics of the Hyphen: Mediating Hispano-Jewish Studies,» Jewish Quaterly Review 91 (2001) pp. 395-409.
} 
Graetz' dependance on Elias Hiam Lindo's The History of the Jews of Spain and Portugal (1848), it could be argued, is not limited to the notes in which this dependance is explicit. It is also apparent in the fact of centering legal history itself. When the mass of papers that constitute Lindo's Nachlass is examined, one may form a definitive opinion about his place in the historiography of the Jews of Spain. Graetz' adaptations of Lindo's History are marked by a stylistic quality which may be discerned in the grand histories of the nineteenth century such as Michelet's: anthropomorphism. ${ }^{5}$ Neuman, whose work presents itself as (partly) institutional, referred to the variety of legal texts on medieval Iberian Jews as «bewildering.» ${ }^{6}$ Barzilai has recently attempted to contextualize Salo Wittmayer Baron's work. For him the main characteristic (in contrast with Baer) is the concern with «the LAW» (sic). ${ }^{7}$ But Baron, writing about medieval Spanish law on the Jews, defined it as «contradictory» and was very dependant on Baer. ${ }^{8}$ Baer, in October 1935, explicitly distanced himself from what he called «Prozedur» in his studies on the Inquisition: «Dagegen legte ich keinen Wert darauf die Prozedur...zu beleuchten.» ${ }^{9}$

It should be clear by now that the assumptions about legal history made by readers of Arragel are less than definitive. There is still room for improvement and research. Thus, for example, one basic fact rarely mentioned by Arragel's readers is fundamental in understanding the legislation -as any other activity- of the Queen

\footnotetext{
5 On Michelet, see Roland BARTHES, Michelet par lui même (Paris 1986); on Graetz, see Eleazar GUTWIRTH, «Sephardi Aristocrats or Rococo Hebraists: On the Social Historiography of Hispanic Jewry,» in The Heritage of the Jews of Spain, ed. A. Doron (Tel Aviv 1994) pp. 103-122.

6 Abraham A. Neuman, The Jews in Spain, vol. I (Philadelphia 1942) p. 19.

7 Isaac E. BARZILAI «Yishak (Fritz) Baer and Shalom (Salo Wittmayer) Baron; two contemporary Interpreters of Jewish History,» Proceedings of the American Academy for Jewish Research 60 (1994) pp. 7-69.

8 Salo W. Baron, A Social and Religious History of the Jews, vol. V (New York 1965) p. 128.

${ }^{9}$ Fritz BAER, Die Juden im christlichen Spanien. Urkunden und Regesten, I/2. Kastilien-Inquisitionsakten (Berlin 1936) «Vorwort,» p. XI.
} 
Regent, Catharine of Lancaster: the accord with Ferdinand. Apart from the differences between Castile and Aragon, ignored by Gutmann and his followers (who see Tortosa and Peñafiel as main factors on activites in Maqueda), there is the fact of the division of the jurisdiction of Castile into two regional areas. ${ }^{10}$ Another point is that not all the items of the legislation of 1412 can be used as new, individual, characteristic proofs of the peculiar atmosphere of that time, because some items have been proved to be merely repetitions of previous legislation. This is precisely what Torres Fontes accomplished in a study ${ }^{11}$ which was apparently unfamiliar to Gutmann and his followers. Above all, there is little engagement with a distinction which underlies the methods of contemporary historians: that between seigneurial and royal jurisdictions. ${ }^{12}$

Ana Domínguez Rodríguez' perspectives on the Arragel Bible come from the vantage point of a long career of scrutiny of imperial and royal manuscripts: those of Carlos V, ${ }^{13}$ Isabel la Católica, but

\footnotetext{
10 Juan TORRES FONTES, «La regencia de don Fernando de Antequera», Anuario de Estudios Medievales 1 (1964) pp. 375-419.

${ }^{11}$ Juan TORRES FONTES, «Moros, judíos y conversos en la regencia de don Fernando de Antequera,» Cuadernos de Historia de España 31-32 (1960) pp. 6097. Evidently there are some elements of apologetics in Torres, and the Hebrew sources have to be attended. Similarly at this seigneurial level of patronage other models may be relevant for reconstructing the situation in the 1420's, the age of the rise of Fernán Díaz de Toledo, El Relator. See Eleazar GuTwiRTH, «Dyl'twr o ryl'twr: Fernán Díaz de Toledo y los Judíos,» Sefarad 46 (1986) pp. 229-234; ID., «The Jews in $15^{\text {th }}$ century Castilian Chronicles,» Jewish Quaterly Review 84 (1984) pp. 379-396.

12 On señorio, amongst many other studies by Encarnación MARín PADILLA, see for example her «Los judíos de la Almunia de Doña Godina, villa aragonesa de señorío en la segunda mitad de siglo XV,» Sefarad 49 (1989) pp. 135-152. On realengo, see for example Javier CASTAÑO, «El procurador de las aljamas de los judíos de Castilla y la carta Real de 1450,» En la España Medieval 18 (1995) pp. 183-205.

${ }^{13}$ Ana Domínguez Rodríguez, «El officium Salomonis de Carlos V en el monasterio de El Escorial,» Reales Sitios XXII/83 (1985) pp. 11-17.
} 
particularly those in the Alfonsine tradition. Therefore, in her opinion, the royal court is the model of culture, and she points to the prevailing lack of interest in the production of illuminations in Arragel's Castile during Juan II's reign around the period 14201450 , despite the literary creativity at court. ${ }^{14}$

Paris is the best known center of manuscript illuminations in the International Gothic style. For her, the «orlas» in the Arragel Bible are «ingenuas imitaciones» of the Parisian models. Similarly, «sus miniaturas no son tan importantes desde el punto de vista de la calidad artística. Las ilustraciones ... son en general muy rústicas y con un trecentismo lejano y un espiritu 'naif' pero lleno de vigor totalmente alejado del refinamiento del Gótico...» (p. 474). The Arragel Bible was illuminated, like other Toledan codices, by «maestros rudos y torpes.» Their character is «acusadamente local, estando mas próximo ... a la pintura naif que a la gran pintura» (p. 475). The painters are «maestros toledanos poco conocedores de lo extranjero» in contrast with the contemporary Toledan «maestro de los cipreses» who had «medios reducidos» but was able to create images of great beauty (p. 376). The figure of God admonishing Cain in the Arragel Biblia is «gruesa y poco elegante» (p. 477). The manuscript illuminations are marked by «el trecentismo usual en este manuscrito» (ibidem).

Nevertheless, the number of the miniatures of the Arragel Bible surpasses all others, with its more than 300 illuminations. ${ }^{15}$ This very richness is, for her, the reason for the lack of comprehensive studies: «por ello es aun más dificil resumir sus méritos.» Domínguez gives us an interesting insight into art history and historians, when trying to assess why certain illuminations of the

\footnotetext{
${ }^{14}$ Ana Domínguez Rodríguez, «Dos Biblias iluminadas en Toledo en torno a 1420: La Biblia de Alba y la Biblia romanceada Escurialense (Escorial Ms I.J.3),» in Flanders in a European Perspective. Manuscript Illumination Aroud 1400 in Flanders and Abroad, eds. Maurits SMEYERS and Bert CARDON (Leuven 1995) pp. 473-485.

${ }^{15}$ On p. 111, Domínguez RodríGuez prefers to count 334 with Domínguez Bordona, rather than Fellous (1992) figure of 325 (p. 476, n. 13). Paz y Melia had already counted the illuminations.
} 
Arragel Bible have become famous (while so many others were practically unknown and not discussed -at least until Fellous' study). What really determines celebrity for her is the «crudeza y violencia» as shown by the popularity of the «Death of Abel» painting. The «Death of Abel» painting was indeed selected for mention -out of more than 300 illuminations- at least as early as 1920, by Paz y Melia (p. XX). And yet it could be argued that even from the point of view of ferocious «crudeza y violencia» it pales in comparison with the bleeding penises of the illumination in the Book of Joshua under the rubric «De como le fiso vn grand monton de los prepucios.» Domínguez Bordona and the Marqués de Lozoya see the age of the Trastámaras, at least until Enrique III, as a period of great scarcity of books. González Dávila spoke of the lack of books «que con muchos florines y trabajo no se podia haber.» ${ }^{16}$ Books were found to be cheaper in France, hence the trend to import the «biblias de Paris.» Domínguez Bordona spoke of the Arragel Bible's «encanto,» part of which was its realism, which he qualifies as «feroz.» In 1920 Paz y Melia (p. XX) had already considered that it had scenes «del más crudo naturalismo». Domínguez Bordona saw the main artistic value in the «enormes esfuerzos... para darnos la sensación del movimiento, para resolver los problemas de la perspectiva.» For the Marqués it is the most important work of Castilian manuscript illumination in the first half of the $15^{\text {th }}$ century. They compare it to the «maestro de los cipreses.»In general, they leave the precise analysis and research to future generations.

For Domínguez, research on the Arragel Bible «no ha hecho más que empezar desde el punto de vista artístico y debe ser relacionado con el arte de la época» (p. 479). In general, one misses attention to

\footnotetext{
${ }^{16}$ On the «Death of Abel» see also Ángela Franco MATA, «El Génesis y Éxodo en la cerca exterior del coro de la catedral de Toledo,» Toletum 21 (1987) pp. 53160, 72ff; Sonia Fellous, "'La Biblia de Alba': L'Iconographie ambiguë,» in Creencias y Culturas, eds. C. CARRETE and A. GinIO (Salamanca 1998) pp. 41-96; Juan de Contreras y LóPez DE Ayala (Marqués de Lozoya), Historia del arte hispánico, vol. II (Barcelona 1931-1948) p. 384, where he cites Domínguez Bordona at length.
} 
certain features of the culture of the period. These come from students of the relations between power and culture but are more concerned with literature, particularly fifteenth century Cancioneros from the courts of nobles and monarchs of Castile. It may suffice to recall that these relations are subsumed in titles such as Potvin's Illusion et pouvoir; Brooke's The Word is the Sword or Nieto Soria's Apología y propaganda.» These could very well apply to the project of the illuminated book commanded by the Master of the Military Order of Calatrava. ${ }^{17}$

III

Morreale's studies on the Arragel Bible have had a less obvious but equally significant influence. One of the traits of her philological approach is the depth and the density achieved by concentrating on well delimited, small units, such as the glossary which accompanies the Bible among others. ${ }^{18}$ It was ostensibly designed by Arragel in order to establish a common «neutral» language which would succeed in avoiding the millennium and a half putative barrier between Christian and Jewish approaches to the same text: the Old Testament.

Morreale's concentration on the glossary has had a productive influence and is followed by various publications. Lorenzo Amigo's studies or some sections of Fellous' book show this in practice despite differences. ${ }^{19}$ Basic to this approach is the view that one

\footnotetext{
${ }^{17}$ Claudine Potvin, Illusion et pouvoir: la poétique du Cancionero de Baena (Montreal 1989), and E. S. BROOKS, The Word is the Sword: A Study of Language Theme and Rhyme in Fifteenth Century Cancionero Poetry (Ann Arbor, Michigan UMI Dissertation Services 1993). José Manuel NiETo SoRIA, «Apología y propaganda de la realeza en los cancioneros castellanos del siglo XV. Diseño literario de un modelo político,» En la España medieval 11 (1988) pp. 185-221.

${ }_{18}$ Margherita MorReale, «El glosario de Rabbi Moses Arragel en la Biblia de Alba,» Bulletin of Hispanic Studies 38 (1961) pp. 145-152.

${ }^{19}$ Lorenzo AMIGo ESPADA, «El influjo del latín en el vocabulario de la Biblia de Alba: algunas voces,» Thesauramata philologica Iosepho Orozio oblata III (= Helmantica 46), eds. Ma Rosa Herrera et al. (Salamanca 1995) pp. 183-200.
} 
cannot dismiss the elements which accompany the translation (such as the Glossary) as mere «appendixes.» It is not entirely clear whether Gerard Nahon's Preface to Fellous' study disagrees. Historically, the attention to the translation as the only main, or legitimate subject of research may be traced back, if not to Villanueva (1791) or Usoz (1847), at least to Berger who developed the thesis that Arragel's was not a new translation, but an elaboration of previously existing traditions. In 1898, he wrote to Paz y Melia (Biblia, XIII): «Nous avons ici une revision plutot qu'une version nouvelle.» He had conversations with Paz y Melia about this matter during a brief visit to Madrid, and his views on the subject were published as early as $1899 .{ }^{20}$

Others have therefore paid attention to less well trodden paths. Thus, for example, the views that Arragel's glosses are insignificant to the project were dismissed. They were seen, quite on the contrary, as important expressions of Jewish thought. ${ }^{21}$ An approach was elaborated where the main questions were concerned with Arragel's selection of particular sources and rejection of others in his glosses, the innovation in presenting so much material in the romance rather than in Hebrew, the breaking of the barrier between lay, non clerical Christians and Jews in the approach to exegesis. By now and after Dagenais' work, amongst others, scholars have been able to assimilate the significance of ethics to the history of reading in the age of the manuscript ${ }^{22}$.

\footnotetext{
${ }^{20}$ Samuel BERGER, « Les bibles castillanes. III,» Romania 28 (1899) pp. $521 \mathrm{ff}$.

${ }^{21}$ Eleazar Gutwirth, «The 'Lower orders,' in $\mathrm{XV}^{\text {th }}$ C. Hispano-Jewish Thought,» Miscelánea de Estudios Árabes y Hebraicos 30 (1981) pp. 83-98.

${ }^{22}$ Eleazar GUTwIRTH, «Arragel on Ruth: Rashi in Fifteenth Century Castilian?,» in Rashi 1040-1990. Hommage à Ephraïm Urbach. Congrès européen des Études juives, ed. G. SED-RAJNA (Paris 1993) pp. 657-662; J. H. Miller, The Ethics of Reading (New York 1987). For the medieval Hispanic/ist context see Paul J. SMITH, «Violence and Metaphysics: La Celestina and the question of Jewish Philosophy,» Michael 11 (1989) pp. 267-285; John DAGENAIS, The Ethics of Reading in Manuscript Culture. Glossing the Libro de Buen Amor (Princeton 1994); Alan D. DEYERMOND, «La literatura en su contexto físico,» Donaire 3 (1994) pp. 9-21.
} 
The old notions that one could tamper with medieval texts such as Arragel's, as presented in the manuscripts with their glosses (as did Paz y Melia who relegated them to the end of the books) and prefaces, rearranging the texts, selecting the center and the margin, have been discredited. It was argued that the glosses were an important subject for research. Similar is the research area of the prefatory matter. Here the case was only apparently different. Some (proportionally minute) paragraphs of the long texts (c. 25 folios) which precede the translation have been endlessly repeated. Perhaps the most famous paragraph is the short paragraph in the second chapter of the prologue which was a central text for Americo Castro: ${ }^{23}$

E esta preheminencia ouieron los reyes e señores de Castilla que los sus judios ssubditos memorando la magnificencia de los sus señores fueron los mas ssabios los mas honrrados judios que quantos oueron en todos los regnos de la su trasmigracion en quatro preheminencias: en linaje, en riqueza, en bondades, en ciencia.

This has led to practices of decontextualization of the material. The medieval translation of Arragel may be better understood in the context of medieval translations. Speaking of this and pondering on the causes why «on ne les a pas beaucoup étudiés...,» Chavy affirms that this is because «leurs oeuvres sont souvent peu accesibles.» ${ }^{24}$ Claude Buridant's study of Translatio medievalis: Theorie et pratique de la traduction médiévale agrees with this view. ${ }^{25}$ In the seventeenth century, Arragel's Bible was already being described as «pesada de volumen y de dificultosa lectura» (Paz y Melia, p. VII). In such a context one selected paragraph could be presented (by Paz y Melia, Castro and many others) as an unmediated reflection of life with no demanding, complex, textual long history of antecedents

\footnotetext{
${ }^{23}$ Américo Castro, España en su historia. Cristianos, moros y judíos (Madrid 1983) p. 476.

${ }^{24} \mathrm{P}$. ChAvy, «Les premiers translateurs français,» The French Review 47 (1974) pp. 557-565.

${ }^{25}$ Claude BURIDANT, «Translatio medievalis. Théorie et pratique de la traduction médiévale,» Travaux de linguistique et de littérature 21 (1983) pp. 81-136.
} 
-in Hebrew and Aramaic, for example. At the other extreme, this tradition of Jewish introductions to translations could be dismissed for precisely the opposite reason. Steinschneider - who cannot be accused of being ignorant of the large and unwieldy field of prologues to medieval Jewish translations- noticed certain aspects of these texts in his Hebräische Übersetzungen. In this as in his Vorlesungen über die Kunde Hebräischen Handschriften, ${ }^{26}$ he sometimes emphasized the presence of topoi and conventional phrases and ideas (such as the pun of 'imre sefer-'imre shefer or the notion of spoils of the Egyptians). This view of the cliched quality of medieval Hebrew/Jewish prologues dominated for a long time. Even Dietrich Briesemeister, who could be original in other aspects, follows Steinschneider's 1890's views in 1980: «Auch bei den jüdischen Übersetzern wurden die Vorreden allmählich in Form und Gedanken Stereotyp» ${ }^{27}$-hence the reluctance to engage in the analysis of texts which, it was felt, could be conventional. Without entering into a polemic about the elements of convention in medieval Jewish prologues (as in every other linguistic construct), it was argued that medieval Jewish prologues to translations could be an interesting source for reconstructing various cultural phenomena (e.g. the attitude to Christianity, ${ }^{28}$ the views of science ${ }^{29}$ ) of Hispano-Jewish history. In this line, the prologue, rather than an appendix, could become a significant subject of research just as the glosses, the rubrics, or the illuminations. When Arragel's prologue argues that he cannot be a courtier of Don Luis de Guzmán, is he reflecting «life» or a long tradition of Hebrew exegesis to the Book

\footnotetext{
${ }^{26}$ Berlin 1892; Jerusalem 1937. It is best consulted in the updated version (transl. Israel ElDAR) Harsa'ot 'al Kitve Yad' Ivriim, ed. A. M. HABERMAN (Jerusalem 1965).

${ }^{27}$ Dietrich BRIESEMEISTER, «Die Theorie der Übersetzung in Spanien im 15. Jahrhundert,» in Stimmen der Romania. Festschrift für W. Theodor Elwert (Wiesbaden 1980) pp. 483-517.

${ }^{28}$ Eleazar GuTwiRTH, «Actitudes judías hacia el cristianismo: Ideario de los traductores Hispano-judíos del Latín,» in Actas II Congreso Internacional Encuentro de las Tres Culturas, ed. C. CARRETE PARRONDO (Toledo 1985) pp. 189-196.

${ }^{29}$ Eleazar GUTWIRTH, «History and Jewish Scientific Study in Medieval Spain,» in La ciencia en la España medieval, ed. Lola FERRÉ (Granada 1992) pp. 163-174.
} 
of Daniel from the Talmud and onwards? ${ }^{30}$ To what extent are the ideas and the stylistic strategies of the prologue unique to Rabbi Moses Arragel? The case of Romance epistolography as a vehicle in which -as everybody agrees- the Rabbi invested so much energy is one of the lines of research. ${ }^{31}$

The recent demise of the great historian of the language, Rafael Lapesa (ob. 2001), has been one of the reasons for the renewed public attention to the work of Américo Castro (1885-1971). According to Lapesa, who was an admirer and an editor of Castro's work, the year 1948 was crucial in Castro's development: «Fecha clave en la producción histórica de Américo Castro fue el año 1948, cuando publicó en su exilio americano España en su historia». ${ }^{32}$ Carmen Castro disagrees. According to her, España en su historia is «un libro que estaba ya terminado en Princeton -abril 1946- y que no apareció hasta 1948 por razones técnicas ajenas a la voluntad de la Editorial Losada». ${ }^{33}$ Neither 1946 nor 1948, one suspects, are the really crucial years, according to Albert Sicroff's article. ${ }^{34}$ Sonia Fellous' title may be a subtle hommage to that of Sicroff.

Albert A. Sicroff is not only a former disciple of Américo Castro in Princeton but also the heir to Castro's own copy of the Rox-

\footnotetext{
${ }^{30}$ Eleazar GUTWIRTH, «Daniel 1,4 y las ansiedades del cortesano», in III Simposio Bíblico Español (I Luso-Espanhol), ed. J. CARREIRA et al. (Valencia Lisboa 1991) pp. 639-648.

${ }^{31}$ Eleazar GUTwIRTH, «Medieval Romance Epistolography: The Case of the Iberian Jews,» Neophilologus 84/2 (Abril 2000) pp. 207-224.

${ }^{32}$ Rafael LAPESA, "Américo Castro,» in Américo Castro, sobre el nombre y el quién de los españoles, ed. Rafael Lapesa (Madrid 1985) n/p.

${ }^{33}$ Carmen CASTRO, «Nota introductoria a la edición de 1983,» in Américo CAStro, España en su historia. Cristianos, moros y judíos (Madrid 1983).

${ }^{34}$ Albert SiCROFF, «The Arragel Bible. A Fifteenth Century Rabbi Translates and Glosses the Bible for his Christian Master,» in Américo Castro. The Impact of his Thought, eds. Ronald E. SURTZ, Jaime FERRÁN, and Daniel P. TESTA (Madison 1988) pp. 173-182.
} 
burghe Club's Arragel Bible. He studied Arragel's Book of Isaiah, but also attended to the contextualization of Castro's thought. For him, the fundamentals of the theory of convivencia may be discerned in Castro's essay in Ortega y Gasset's El Sol of January 26, 1923. The essay was a review of the publication by the Roxburghe Club under the name of the Duke of Alba, of the Paz y Melia family's (both Antonio and Julián) edition and introduction of Arragel's work. The Roxburghe Club publication of Arragel is thus presented as the foundational act and the origin of one of the most influential and comprehensive theories of Spanish culture of the twentieth century. The Roxburghe Club edition is still -even after the facsimile of 1992- the standard one. Fellous herself refers to the Roxburghe Club edition rather than to the facsimile in her notes. Castro's attention to Arragel in 1946 postulated the notion of «tolerance» (p. 477: «bello ejemplo de tolerancia»), and it was still repeated half a century later, as is Castro's notion that Pedro de Toledo's translation of the Guide for Gómez Suárez de Figueroa is a significant work which should be studied and published (p. 477: «cosa que debe hacerse»), and that, likewise, yet another element of Arragel's context is the translation of the Libro de sabios e philosophos for the maestre de Santiago, Don Lorenzo Suárez de Figueroa by don Jacob Çadique de Uclés in 1402. Berger and Paz y Melia himself, among others, were able to contribute -in different ways-to Arragel studies before the Roxburghe Club publication. And yet, even those (Samuel Armistead, Domingo Ynduráin, and myself ${ }^{35}$ ) who have emphasized other factors in the development of Castro's thought can hardly deny the impact of the Roxburghe Club's publication thereupon and certainly on the development of Arragel studies.

\footnotetext{
${ }^{35}$ See Samuel ARmistead, «Américo Castro in Morocco,» in Américo Castro. The Impact of his Thought, pp. 73-82; Domingo YNDURÁIN, «La crítica histórica y literaria de Américo Castro y su escuela: Hacia una valoración,» in Judíos, sefarditas, conversos. La expulsión de 1492 y sus consecuencias, ed. Ángel AlCALÁ (Valladolid 1995) pp. 577-586; Eleazar GUTwIRTH, «The Politics of the Hyphen.» For Sicroff, Nordström and other studies on Arragel, see also Eleazar GUTWIRTH, «Arragel on Ruth: Rashi in Fifteenth Century Castilian?».
} 
The question of technologies of mechanical reproduction -in this case of a unicum - and their impact on critical thought come, thus, to the fore. In the case of iconography and art history, the impact is clear. Fellous' book has superb, intelligently selected reproductions. It is clear, after studying her book, that previous contributions engaged with only a small proportion of the material, and had to pay less attention to some of the aspects. The lack of sustained systematic attention to colouring before Fellous is yet another example of the impact of technology and access. The visual, metatextual messages in the colouring of different parts of the Bible (e.g. the rubrics, or, sometimes, particular words) can now be better analysed than in the Paz y Melia edition. Although nineteenth and twentieth century scholars of manuscripts were perfectly well aware of the medieval book as a physical object or an artifact, in recent years there has been some progress. Metzger sees Arragel's area and period as one in which, rather than unmitigated decline, there is both tradition and innovation with regard to the mise en page and calligraphy. For METZGER, calligraphy includes, to be sure, the art of the beauty of the characters, but also «l'harmonie de la mise en page et en particulier ... rapport entre module des caractères et longueur et espacement des lignes ainsi qu'à la réguliere alternance des blancs et des noirs dans la ligne et dans la page. ${ }^{36}$ In the case of the Arragel Bible, both the facsimile and Fellous' study show that this whole dimension of Jewish culture and aesthetics cannot be understood by users of the technologies of mechanical reproductions of the 1920's. The relations between technologies of mechanical reproduction and critical thought in general have been understood some time ago. In La conquête de l'ubiquité Paul Valéry wrote:

«Our fine arts were developed, their types and uses were established, in times very different from the present, by men whose

\footnotetext{
${ }^{36}$ See her paper of May 1992 entitled «Les arts du livre chez les juifs d'Espagne,» in 1492. L'Expulsion des juifs d'Espagne, ed. R. GoETSCHEL (Paris 1995) pp. 163-182.
} 
power of action over things was insignificant in comparison with ours. But the amazing growth of our techniques, the adaptability and precision they have attained, the ideas and habits they are creating, make it a certainty that profound changes are impending ... In all the arts, there is a physical component which can no longer be considered or treated as it used to be ... We must expect great innovation to transform the entire technique of the arts thereby ... bringing about an amazing change in our very notion of art...» ${ }^{37}$

Paul Valéry's statements constitute the opening epigraph of Walter Benjamin's The Work of Art in the Age of Mechanical Reproduction. ${ }^{38}$ Walter Benjamin's attention to this in 1934/35 has had a lasting effect. For him, «the situation into which the product of mechanical reproduction can be brought may not touch the actual work of art, yet the quality of its presence is always depreciated» (Section One). Benjamin also brings into play the question of creativity and authenticity, which inevitably leads to the question of originality and unoriginality. One may therefore attend to the question of the particular circumstances of this publication, that is, the question of the history and character of the Club that served as a platform for Arragel. ${ }^{39}$

The Roxburghe Club is the oldest existing society of bibliophiles in Great Britain and probably in the world. It was founded in 1812 by Reverend Thomas Frognall Dibdin, curate in Kensington, who became a bibliographer and protégé of the second Earl Spencer. He thrived under Lord Spencer's patronage with the help of the Althorpe Library. The third duke of Roxburghe, born in 1740, was a contemporary of George III. He fell in love with Christine of Mecklenburg-Strelitz, but did not marry her. He was, nevertheless, a favourite at court when her sister Charlotte became Queen of

\footnotetext{
${ }^{37}$ Paul VAlÉRY, «Pieces sur l'art,» in The Conquest of Ubiquity, tr. Ralph Manheim (New York 1964) p. 225.

${ }^{38}$ Walter BENJAMIN, Illuminations (New Cork 1967).

${ }^{39}$ For what follows see [Lieut. Col.] Clive BIGHAM, The Roxburghe Club and its members 1812-1927 (Oxford 1928); Nicolas BARKer, Publications of the Roxburghe Club 1814-1962 (Cambridge 1964) [Table in pp. 67-99]; Valerie M. LAGORIO, «The Roxburghe Club Collection,» in Books at lowa 35 (November 1981).
} 
England. He was a book collector and filled his house in St James Sq. with books. At his death in 1804, his books were sold for 23.000 pounds. Debdin assembled a dinner at Waterloo Place on the occasion of the sale of the Valdarser Boccaccio of 1471 (it was acquired by the Marquis of Blandford at 2.260 pounds. It had originally cost 100). The dinner took place on Wednesday $17 / 6 / 1812$. The members of the Club had fine libraries and made toasts in honour of the famous printers. It was decided to have an annual dinner on that date. Dibdin's patron-Spencer- was made president. He was a patron of Nelson, ambassador in Vienna, Trustee of the British Museum. At the first anniversary, in 1813, it was resolved that each member should reprint some small piece of ancient lore to be given to the others, one copy being on vellum for the chairman, and they should make as many copies as members. In the early years there were gastronomic interests. In 1818 it extended its horizons to France. Dibdin gave a dinner in Paris to bibliophiles. In 1823, Walter Scott joined it. In 1839 its members increased to forty.

The Club had a strong medieval interest as shown in about 48 of its publications (e.g. Barker's list includes Poems written during captivity by Charles Duke of Orleans [44]; The Owl and the Nightingale [54]; The Alliterative Romance of Alexander [67]; Gower's Vox Clamantis, etc). The editors of these medieval editions included renowned medievalists such as Frederick Madden, Thomas Wright, F. J. Furnivall. The latter was not in favour of the limited editions, a criticism which had its precedents. He realized that this was not consistent with the aims of promoting scholarship. He split from the Club and formed the Early English Text Society.

By 1884 , the Club had deteriorated to such an extent that its abolition was contemplated at a meeting with nine people in attendance. Seven voted against the motion. At this time its interest in facsimiles began to develop. It was concurrent with the progress in the photolitographic field.

From a scholarly perspective, M. R. James' (1862-1936) association could be a symbol of its revival. He edited around 13 manuscript facsimiles for the Club. The biblical manuscripts may be more interesting from our point of view, such as the Trinity College 
Apocalypse [155]; A Petersborough Psalter and Bestiary of the $X I V^{\text {th }}$ Century [178]; Illustrations of the Book of Genesis [177]. He was, in a certain way, representative of the peculiar tensions between power and culture in the Club. He had served as Provost of Kings College, Cambridge and later of Eton. The more evident relations between political power and culture occur from 1884 and onwards. Then, the Club is joined by Lowell, the American envoy to the court of St. James and two prime ministers, Salisbury and Rosebery. In 1891, they began to dine in private.

Jacobo María del Pilar Carlos Manuel Stuart Fitz James was the $17^{\text {th }}$ Duke of Alba and the $10^{\text {th }}$ of Berwick. He was born in 1878 of Carlos and María del Rosario Falcó y Osorio, $22^{\text {nd }}$ Condesa de Siruela. He was educated at Beaumont College and married, in 1920, María del Rosario, daughter of the $13^{\text {th }}$ duke of Aliaga. By 1928, he was no longer deputy but senator at the Cortes, honorary member of the Academias (Lengua, Historia, San Fernando). He joined the Club in 1917. The Biblia was the $179^{\text {th }}$ edition of the Club.

The question of authorship comes to the fore. The name of Arragel's Bible has been questioned, and popular usage ascribes it to the Duke. In his introduction, Paz y Melia refers to «cuartillas,» that is, technically, a quarto or fourth of a «pliego» and half a folio. $\mathrm{He}$ asserts publicly that he filled, by hand, around 11.000 «cuartillas» with his (and his son's) transcriptions from the fifteenth century codex. And yet, it is not his name which appears in the title. This is clearly related to the question of authorship and intellectual property. This is not only the case with the Biblia. In 1933, for example, there appeared an essay on The pharos of Alexandria which is included in catalogues under the Duke's name (albeit as subsidiary) and is described as a «Summary of an essay in Spanish by Don Miguel de Asín (With architectural commentary by Don M. Lopez Otero) Communicated by the Duke of Alba... in $8^{\circ} . \gg$ Such lists include the Discurso sobre la forma de reducir la disciplina 
militar a mejor y antiguo estado by Sancho de Londoño y de Ariz, published in Madrid in 1943. It is in $4^{\circ}$ with a dedicatory Epistle by the Duke of Alba, whose authorship -as far as I know- has not yet been questioned by bibliographers. ${ }^{40}$

Questions of intellectual ownership have not been absolutely resolved in disciplines such as Law, Philosophy or intellectual history. But in this case, they affect more than the twentieth century transmissions. Indeed, to what extent can we say that the Bible translation is Arragel's when there is influence of the Vulgate, contact with other Biblias romanceadas and some theories claim that it is a reworking of previous efforts? To what extent is the commentary original of Arragel? To what extent have been the ideas of the prefatory matter (i.e. the Epistle at the beginning) a no textual precedent? The notion that the sources were competently dealt with in 1899 by Paz y Melia's article dissolves upon closer scrutiny despite continuous repetition. ${ }^{41}$ The study of «presences,» Aristotelian or otherwise, is not really an alternative to facing questions of what was the text behind Arragel's comments. The Arragel project may be less simple than it looks, even without the fantastic claims made for it.

Similarly, the question of the Duke's role is much less clear than his image in the popular imagination. Don Jacobo himself liked to construct an image of intimacy and close collaboration with don Antonio, remembering when they were around the table, working on common projects. Here, I have tried to raise the question of the roles of technology, discipline and power politics. The usual explanations of general cultural activity in this period refer to

${ }^{40}$ See the note by Francisco CANTERA, Sefarad 4 (1944) pp. 211-212.

${ }^{41}$ For his Hebrew it may suffice to glance at (let alone read) p. xvi. The sources' list which is the basis for many assertions about Arragel to this day does not indicate where Arragel mentions these authorities. He is highly dependant on Rodríguez de Castro. 
«regeneracionismo» and the «generación del 98.» Recently, however, the notion has been questioned. ${ }^{42}$

The Duke himself refers to his loyalty to «la Casa» as the impulse for the project. But, albeit briefly, he also refers to the figure of the mother. ${ }^{43}$ There is a certain contradiction in these myths of origin. They concern the dates (1899? 1917? 1920-22?) and aims of the project, but there is also the question of gender. Is it the all male London Club, the male friendship with (or sponsorship of) don Antonio or is it the Duchess who is the main source and origin of the idea? Nordström (p. 12) and even more recently and explicitly Adriaan Keller seem to accept without any critical qualms that the Duchess is in fact the author of the Catálogo de las colecciones expuestas en las vitrinas del Palacio de Liria. Le publica la Duquesa de Berwick y Alba, Condesa de Siruela (Madrid 1898). Here we already find an engagement with the description of the binding of the codex, however primary: as Keller affirms in 1992, «the Duchess of Berwick and Alba gives this description in her Catalogue... a binding of silk interwoven with gold thread.» ${ }^{44}$ The accounts of the first substantial study on Arragel of 1899 (almost identical with the study which introduces the edition in 1920) transport us to a slighltly different milieu. ${ }^{45}$ The friendship of the Duchess with don Marcelino Menéndez Pelayo drove her to encourage Paz y Melia to amplify a study which a French journal had just published. The project, then, is seen as a Madrid amplification of a Parisian (Ber-

\footnotetext{
${ }^{42}$ For the invention of the generation of 1898 see Joan Ramon RESINA, «A spectre is haunting Spain: The spirit of the land in the wake of the Disaster,» Journal of Spanish Cultural Studies 2/2 (2001) pp. 169-186.

${ }^{43}$ See DuQue DE ALBA, «Necrológica de Don Antonio Paz y Melia,» Boletín de la Real Academia de la Historia 90 (1927) pp. 249-259: pp. 249-251.

${ }^{44}$ See his contribution to the Companion volume of the facsímile ed. Schonfield [cf. supra n. 1], p. 155

${ }^{45}$ Antonio PAZ Y Melia, «La Biblia de la Casa de Alba,» Homenaje a Menéndez $y$ Pelayo, vol. 2 (Madrid 1899) pp. 5-93. It would seem that his problematic context of patronage and authorship can be traced to earlier years. The Fondo Marcos Jiménez de la Espada at the CSIC Archives includes a letter by Paz y Melia to Jiménez de la Espada in 1884 to the effect «que por tener que sustituir a un compañero ha tenido que dejar de copiarle el manuscrito que le encargó» (Reg. 0001379).
} 
ger's) idea. It is offered as a «homenaje» to Menéndez Pelayo. Menéndez Pelayo himself described the Arragel Bible as «insigne monumento de ciencia y tolerancia.» He examined Arragel's translation of the Bible in order to understand Lope de Vega's dramatic ideas on «la primera culpa del hombre.» ${ }^{46}$

\section{RESUMEN}

La Biblia de Arragel es el resultado del trabajo de Rabbi Moshe Arragel y de otros durante el periodo 1422-30/33. Se trata de un códice extenso que incluye textos en al menos cinco géneros diferentes, así como más de trescientas miniaturas. La investigación sobre esta obra medieval tiene ya más de un siglo. Hoy en día, por tanto, es posible analizar esta historia e indagar acerca de algunos de los factores que determinan sus peculiaridades, tradiciones y cambios. Apropiaciones politicas, tradiciones institucionales o disciplinarias, y cambios tecnológicos son factores que determinan esta clase de estudios. Así, además de señalar algunos aspectos relevantes de la historia de la investigación, se presta también atención a: a) el problema de la relación entre crítica y tecnologías de reproducción (fotolitografía, industria del facsímil); y b) el marco institucional (historia del Roxburghe Club) y su papel en la producción del saber.

PAlabras Clave: Historia de la investigación, traducciones medievales, judíos, España del siglo XV.

\section{SUMMARY}

Rabbi Moshe Arragel and other scholars composed in the years 1422-30/33 the Arragel Bible. It is an extensive work that includes several texts in at least five different genres, as well as more than three hundred illuminations. Scholarly research on this medieval codex has been carried out now for more than one century. It is therefore possible today to analyse and investigate some of the factors that define its particularities, traditions and changes. Political interests, institutional or scholarly traditions and technological changes are factors that determine this kind of studies. Attention is drawn to: a) issues of technological reproduction (photolithography or facsimile industry) in determining criticism, and b) the role played by institutions (such as the Roxburghe Club) in the making of knowledge.

KEYWORDS: History of scholarship, Medieval translations, Jews, $15^{\text {th }}$ - century Spain.

${ }^{46}$ See Juan Prado, «Menéndez Pelayo y los estudios bíblicos en España,» Sefarad 16 (1956) pp. 259-312. 